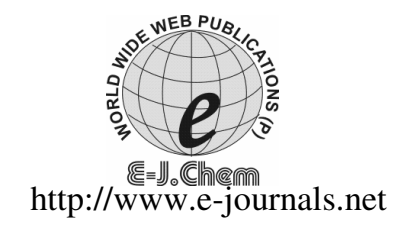

\title{
Studies on Production and Chemical Property of Singlet Oxygen and Superoxide Radical by Dyestuffs
}

\author{
VIKESH KUMAR, M.R.TRIPATHI*, MANISH KUMAR, \\ GOPAL SHUKLA, SARVESH DWIVEDI, VANDANA SHARMA \\ Department of Chemistry, \\ D.A.V.P.G. College, Kanpur 208001 Uttar Pradesh, India. \\ tripathimadhoram@yahoo.co.in
}

Received 15 May 2009; Accepted 10 July 2009

\begin{abstract}
There are several low lying singlet oxygen $\left({ }^{1} \mathrm{O}_{2}\right)$ and superoxide radical $\left(\mathrm{O}_{2}^{-}\right)$which are important in photochemical oxidation. In our present analysis we are studying chemical property of singlet oxygen $\left({ }^{1} \mathrm{O}_{2}\right)$ and super oxide radical $\left(\mathrm{O}_{2}^{-}\right)$and some dyestuffs species to produce reactive oxygen such as singlet oxygen ${ }^{1} \mathrm{O}_{2}$ and superoxide radicals. Irradiation with sun light in vitro the dyestuff like benzanthrone, metanil yellow and $p$-aminodiphenylamine were found to produce reactive oxygen species such as singlet oxygen $\left({ }^{1} \mathrm{O}_{2}\right)$ and/or superoxide radicals $\left(\mathrm{O}_{2}^{-}\right)$. The dose response relationship between singlet ${ }^{1} \mathrm{O}_{2}$ production when sunlight expose of those dyestuffs (0-25 $\mathrm{min})$, and (0-12 $\mathrm{min}$ ) for super oxide $\left(\mathrm{O}_{2}^{-}\right)$production were studied .However benzanthrone produces detectable amount of ${ }^{1} \mathrm{O}_{2}$, Although metanil yellow and $p$-aminodiphenylamine ( $p$-ADPA) did not produce detectable amounts of ${ }^{1} \mathrm{O}_{2}$ under similar conditions. The above dye stuffs are routinely used in textiles, cosmetics, detergents, leather industries as well as food additives and role of these activated oxygen species in the development of skin diseases.
\end{abstract}

Keywords: Dyes, Benzanthrone, Photosensitization, Singlet oxygen, Superoxide radicals and Chemical property,

\section{Introduction}

Production of synthetic dyes in India about 25000 metric tons every year ${ }^{1}$. Which are Industrial health hazards to people ${ }^{2}$. Dyestuff industries have occupied a prominent place in the industrial organization of the modern world. One of the major routes to incorporate dyestuffs in our biological system is by absorption through skin. Some dyes have different degrees of binding ability with protein, collagen and lipids ${ }^{3-4}$. Study shows that toxic effect of these synthetic dyes are observed in the presence of the ultraviolet component of sunlight 
$(285-400 \mathrm{~nm})^{5}$. Photosensitization reactions in our analysis is oxygen dependent in which a photo excited dye transfers energy to molecular oxygen to produce activated oxygen species like singlet oxygen $\left({ }^{1} \mathrm{O}_{2}\right)$, superoxide radical $\left(\mathrm{HO}_{2}\right.$ or $\left.\left(\mathrm{O}_{2}^{-}\right)\right)$, hydroxyl radical $(\mathrm{OH})$ and hydrogen peroxide. The activated oxygen species contribute to oxidative degradation of protein, enzymes, lipids and other target molecules of cellular systems ${ }^{6-8}$ and are also responsible to act as tumor promoters in the development of cancer'.

In present study, the reason for taking benzanthrone ( $7 H$-benz(de)anthrance-7-one) is used in the synthesis of many vat and disperse dyes. It has been observed that workers coming into contact with it during manufacture, pulverization and storage develop itching, burning sensation, erythema, roughness, dryness and pigmentation of the $\operatorname{skin}^{10-11}$. Orange II [monoazo, C.I. acid yellow, orange 7 (15510)], a sodium or calcium salt of $p$-(2-hydroxyl-1naphthalenyl) azo benzenesulfonic acid is used in dyeing of paper, soaps etc ${ }^{12}$. A blend of orange II with metanil yellow under the trade name to cause deleterious effects in our biological system ${ }^{13}$. Metanil yellow [monoazo, C.I. acid yellow 36 (13065)], a sodium or calcium salt of $m$-( $p$-anilinophenyl-azo) benzenesulfonic acid, is used in the coloring of foodstuffs, soaps, shoe polishes, wood stains, paper staining and cosmetics. $p$-Aminodiphenylamine ( $p$-ADPA) and metanilic acid are important metabolites of metanil yellow $^{14}$ and are considered to be an active ingredient of metanil yellow induced toxicity ${ }^{15}$. $p$-ADPA is used as an intermediate for the synthesis of photographic chemicals, and the manufacture of dyeing reagents ${ }^{16-17}$. It is also used as an ingredient in oxidizing types of hair dyes $^{18}$. Its properties of skin irritation and sensitization are well known ${ }^{19}$.

\section{Experimental}

Benzathrone was obtained from kalyan Dye Stuff Industry, Kalyan, Bombay. Metanil yellow and orange II were obtained from M/s Visco Products Pvt.Ltd., Metanilic acid and nitro blue tetrazolium (NBT) were procured from Sisco Research Lab., Bomaby. 1,4-Diazabicyclo- (2,2,2)- octoane (DABCO), p-ADPA, superoxide dismutase (SOD) and $N, N$-demethyl-p-nitrosoaniline (RNO) were obtained from Sigma ChemicalCo., U.S.A. Sodium azide and histidine (HIS) were obtained form HiMedia Lab., Bombay. Other chemicals and solvents used throughout the study were of analytical grade and obtained form E. Merck- BDH Chemical Company. The dyes were further purified by column chromatography.

Ultraviolet and visible spectra were recorded on a Shumatzu 450 UV-visible spectrophotometer using quartz cells of $5 \mathrm{~cm}$ path length. Irradiation experiments were done as follow: $10 \mathrm{~mL}$ solutions were taken in a Petri dish $(6 \mathrm{~cm}$ diameter $)$ and irradiated with direct sunlight. The temperature was maintained at $20 \pm 2{ }^{\circ} \mathrm{C}$ by using a constant temperature water bath. Irradiation experiments were done in Kanpur, U.P. on sunny days preferably between 9:00 and 11.00 am. The irradiance of emitted light was measured by an International Light IL-730 UV Actinic Radiometer (International Light Company, Newburyport, Mass., U.S.A.) equipped with a calibrated and cosine - corrected ultraviolet radiation detecting probe. Sunlight produced an average ultraviolet radiation of approx. $1.2 \pm 0.1 \times 10^{-2} \mathrm{erg} . \mathrm{mm}^{-2} . \mathrm{s}^{-1}$ in the UV-A range $(320-400 \mathrm{~nm})$. It also produced approx. $1.0 \pm 0.1 \times 10^{-4} \mathrm{erg} . \mathrm{mm}^{-2} \cdot \mathrm{s}^{-1}$ of UV-B $(285-320 \mathrm{~nm})$ radiations under similar conditions. The results of intensity measurement were also confirmed by chemical actinometry ${ }^{20}$. Formation of ${ }^{1} \mathrm{O}_{2}$ was determined in aqueous solutions by the method of Kraljic and Mohsini ${ }^{21}$. With water insoluble chemicals, reactions were done in dimethyl formamide (DMF) solution (5$20 \%$ in $0.01 \mathrm{M}$ phosphate buffer, $\mathrm{pH} 7$ ). A $10 \mathrm{~mL}$ solution of $\mathrm{RNO}$ was prepared in a 
phosphate buffer $(0.01 \mathrm{M}, \mathrm{pH} 7)$ and optical density was adjusted between 1.2 and 1.4. Histidine $\left(1 \times 10^{-2} \mathrm{M}\right)$ was added to the RNO solution as a selective acceptor of ${ }^{1} \mathrm{O}_{2}$. Stock solutions $(1 \mathrm{mg} / \mathrm{mL})$ of test compounds were prepared in ethanol, DMF or dimethyl sulfoxide (DMSO). RNO and HIS samples were irradiated with various concentrations of test compounds $(0.1,1.0$ and $10 \mu \mathrm{g} / \mathrm{mL})$ and sunlight dose $(0-25 \mathrm{~min})$. Singlet oxygen forms a transannular peroxide intermediate with HIS leading to the bleaching of ${ }^{1} \mathrm{O}_{2}$ was also established by examining the reaction kinetics in $\mathrm{D}_{2} \mathrm{O}$ and by carrying out quenching studies with sodium azide ${ }^{22}$ and $\mathrm{DABCO}^{23}$. Solvents like $\mathrm{D}_{2} \mathrm{O}$ and $\mathrm{C}_{2} \mathrm{H}_{5} \mathrm{OH}$ are known to prolong the life time of singlet oxygen ${ }^{24}$. Formation of $\left(\mathrm{O}_{2}^{-}\right)$was studied by monitoring the photosensitized reduction of $\mathrm{NBT}^{25}$ with some modifications. Reduction of NBT by $\left(\mathrm{O}_{2}^{-}\right)$ leads to the formation of a blue colored product (nitro blue formazan), which is quantitatively estimated spectrophotometrically at $560 \mathrm{~nm}$. A $1.67 \times 10^{-4} \mathrm{M}$ solution of NBT was prepared in carbonate buffer $(0.01 \mathrm{M}, \mathrm{pH} 8)$ containing 5-20\% DMF to keep the reaction product in solution. $10 \mathrm{~mL}$ solutions were irradiated with various concentrations of test samples in sunlight for varying lengths of time. Further evidences for the generation of $\left(\mathrm{O}_{2}^{-}\right)$were obtained by performing quenching studies with $\mathrm{SOD}^{26}$.

\section{Results and Discussion}

\section{Singlet oxygen production}

A comparative study of the ${ }^{1} \mathrm{O}_{2}$ producing ability of various dyes are studied. Only benzathrone was found to generate sufficient ${ }^{1} \mathrm{O}_{2}$ to be monitored spectrophotometrically by a drop in optical density at $440 \mathrm{~nm}$ due to bleaching of RNO by the transannular peroxide intermediate of HIS and ${ }^{1} \mathrm{O}_{2}$. The ${ }^{1} \mathrm{O}_{2}$ generating potential of benzathrone was comparable to well known photosensitizing agents like anthracene.

Singlet oxygen ${ }^{27}$

The lowest energy electron configuration of $\mathrm{O}_{2}$, which contains two electron in $\pi$ orbital's, gives rise to three states is given in Table 1.

Table 1. States of $\mathrm{O}_{2}$ molecule.

\begin{tabular}{cccc}
\hline State & $\pi_{\mathrm{a}}{ }^{*}$ & $\pi_{\mathrm{b}}{ }^{*}$ & Energy \\
\hline${ }^{1} \Sigma_{\mathrm{g}}^{+}$ & 年 & $\frac{}{\vee}$ & $155 \mathrm{~kJ}\left(\sim 13,000 \mathrm{~cm}^{-1}\right.$ \\
\hline${ }^{1} \Delta_{\mathrm{g}}$ & $\uparrow_{\downarrow}$ & - & $92 \mathrm{~kJ}\left(\sim 8,000 \mathrm{~cm}^{-1}\right)$ \\
\hline${ }^{3} \Sigma_{\mathrm{g}}^{-}$ & $\uparrow$ & $\varpi$ & $0($ ground state $)$ \\
\hline
\end{tabular}

The ${ }^{1} \Delta_{\mathrm{g}}$ states has a much longer life time than the ${ }^{1} \Sigma_{\mathrm{g}}^{+}$states ${ }^{28}$. The life time is solvent dependent, varying by order of magnitude in organic solvents. There are two main ways of generating the singlet oxygen molecules: 1 photo chemically by irradiation in presence of sensitizer and 2 chemically. The photochemical route proceeds as follows, where sense represents the photo sensitizer as shown in equation from 1 to 4

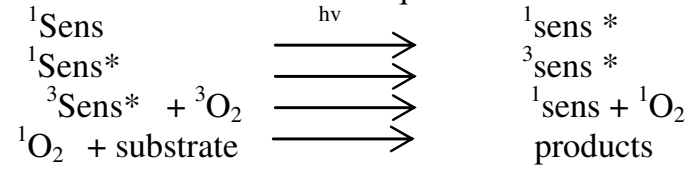

Energy transfer from triplet excited ${ }^{3}$ sens $*$ to ${ }^{3} \mathrm{O}_{2}$ to give ${ }^{1} \mathrm{O}_{2}$ is a spin allowed process A representative example is the use of excited azoalkane with $\mathrm{O}_{2}{ }^{29}$. 


\section{Dose-response relation}

The formation of ${ }^{1} \mathrm{O}_{2}$ from benzathrone was found to be both concentration and sunlight dose-dependent. A nearly linear relationship was found between the concentration of benzathrone $(1-10 \mu \mathrm{g} / \mathrm{mL})$ and the amount of ${ }^{1} \mathrm{O}_{2}$ produced after $25 \mathrm{~min}$ exposure with sunlight Figure 1 . The study was done using a $10 \mu \mathrm{g} / \mathrm{mL}$ concentration of benzanthrone. The order of food stuffs tested aganaist chemical agent for $\left(\mathrm{O}_{2}^{-}\right)$production are benzanthrone $>$ metanil yellow $>p$ - ADPA were found (as shown in Figure 2, $3 \& 4$ ).

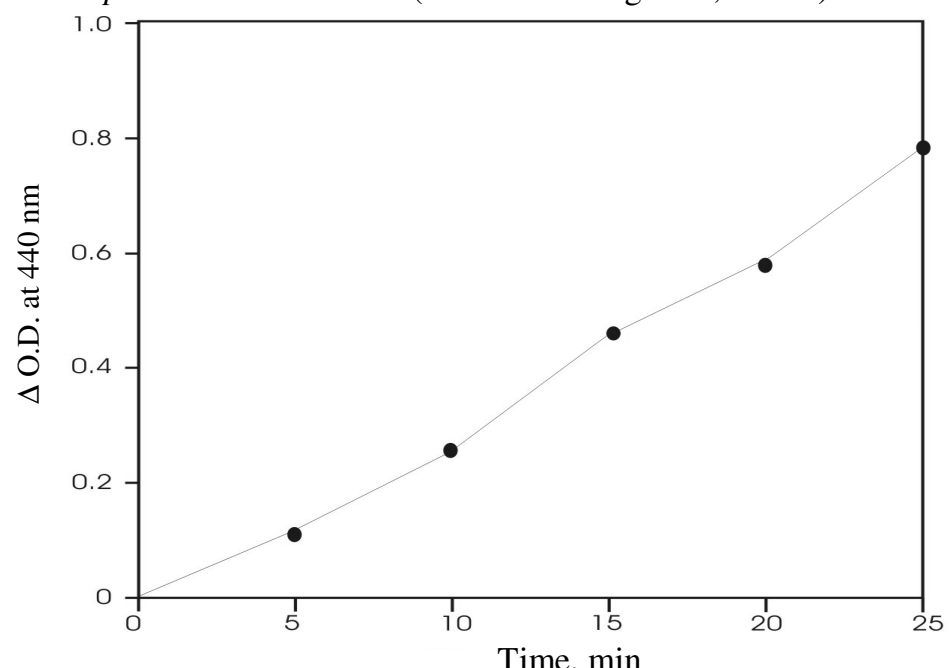

Figure 1. Dose-response relationship between ${ }^{1} \mathrm{O}_{2}$ production and sunlight exposure of benzanthrone $25 \mathrm{~min}$.

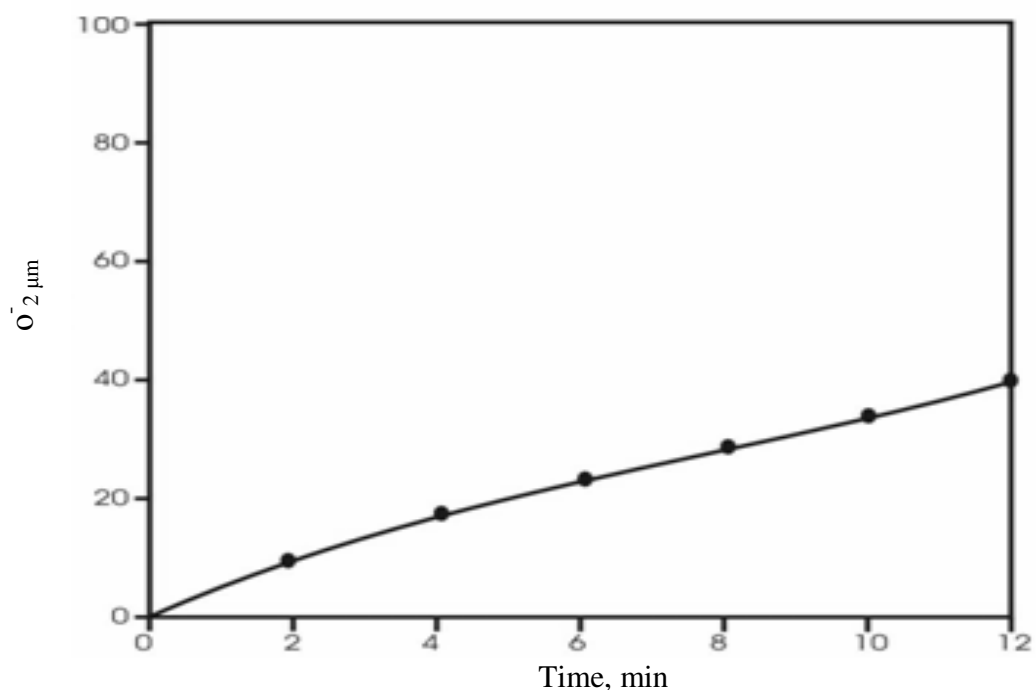

Figure 2. $\mathrm{O}_{2}^{-}$production by photosensitized reduction of NBT $\left(1.6 \times 10^{-4} \mathrm{M}\right.$ in $\left.0.01 \mathrm{M}\right)$ carbonate buffer with 5-20\% DMF, pH 8 using $10 \mu \mathrm{g} / \mathrm{mL}$ of the metanil yellow (reaction time $12 \mathrm{~min}$.) 


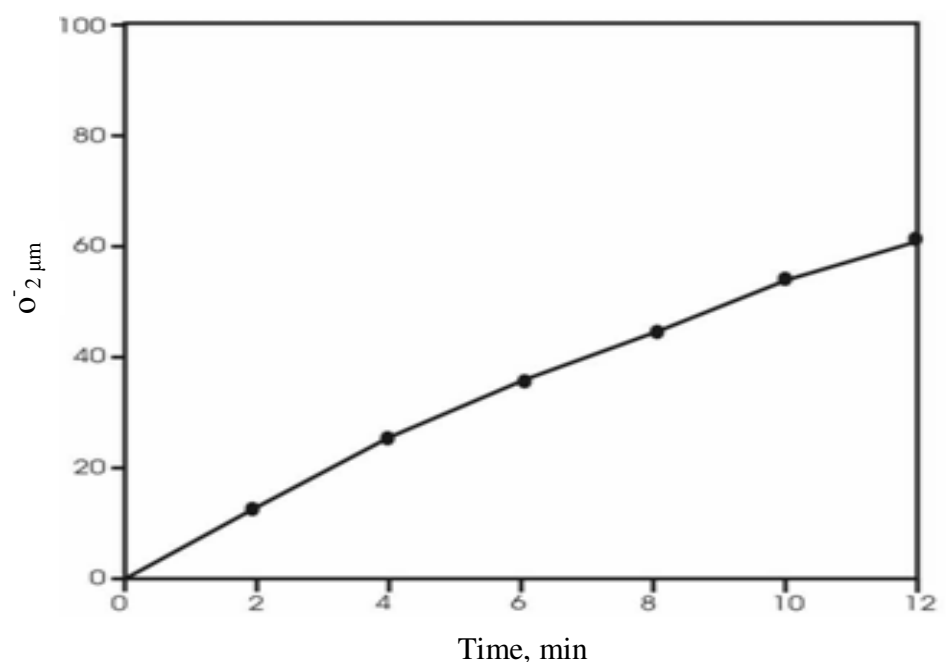

Figure 3. $\mathrm{O}_{2}^{-}$production by photosensitized reduction of NBT $\left(1.6 \times 10^{-4} \mathrm{M}\right.$ in $\left.0.01 \mathrm{M}\right)$ carbonate buffer with $5-20 \%$ DMF, $\mathrm{pH} 8$ using $10 \mu \mathrm{g} / \mathrm{mL}$ of the $p$-ADPA (reaction time 12 min.)

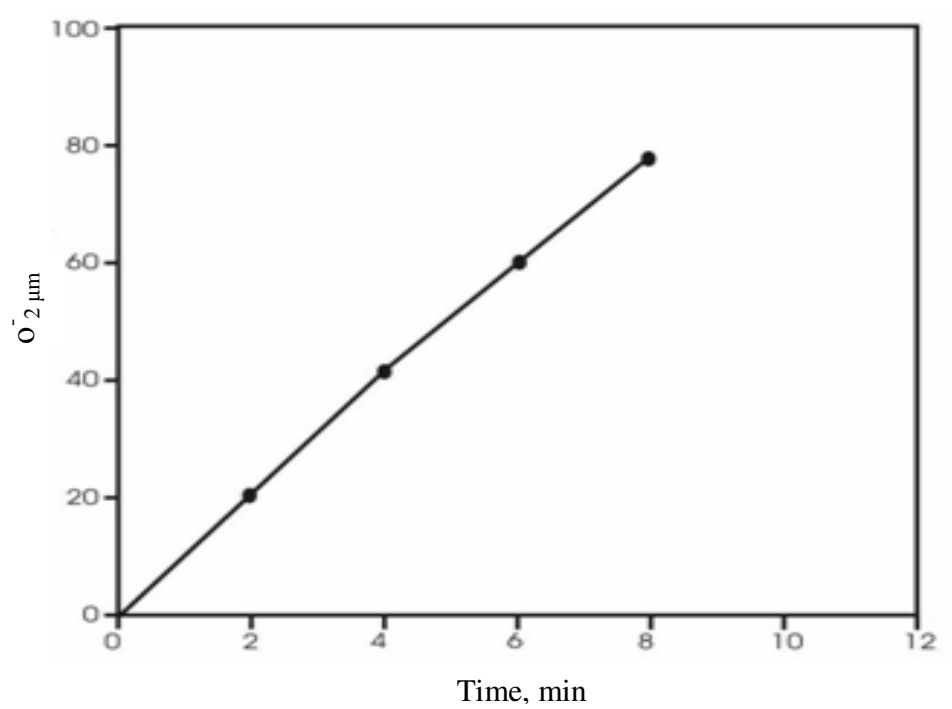

Figure 4. $\mathrm{O}_{2}^{-}$production by photosensitized reduction of NBT $\left(1.6 \times 10^{-4} \mathrm{M}\right.$ in $\left.0.01 \mathrm{M}\right)$ carbonate buffer with 5-20\% DMF, pH 8 using $10 \mu \mathrm{g} / \mathrm{mL}$ of benzanthrone (reaction time 12 min.)

\section{Superoxide radical's production}

There are several low lying singlet states that are important in photochemical oxidation .Like NO, which has one unpaired electron in an antibonding $\left(\pi^{*}\right) \mathrm{MO}$, oxygen molecules associate only weakly, and true electron pairing to form a symmetrical $\mathrm{O}_{4}$ species apparently does not occur even in solid. Both liquid and solid $\mathrm{O}_{2}$ are pale blue. The comparative study of the various bond values for dioxygen species is summarized in Table 2. 
Table 2. Various bond values for dioxygen species.

\begin{tabular}{cccc}
\hline Species & O-O Distance, $\AA$ & Number of $\pi^{*}$ electron & $\mathrm{V}_{\infty}, \mathrm{cm}^{-1}$ \\
\hline $\mathrm{O}_{2}{ }^{+}$ & 1.12 & 1 & 1905 \\
$\mathrm{O}_{2}$ & 1.21 & 2 & 1580 \\
$\mathrm{O}_{2}^{-}$ & 1.33 & 3 & 1097 \\
$\mathrm{O}_{2}^{2-}$ & 1.49 & 4 & 802 \\
\hline
\end{tabular}

\section{Chemical property of dioxygens}

Oxygen combines with almost all other elements, usually however, only on heating. Dioxygen will some time react reversibly ${ }^{30}$ with certain metal complexes and their ligand behavior of $\mathrm{O}_{2}$. Many studies have been made on the mechanism ${ }^{31}$ of the reduction of $\mathrm{O}_{2}$ There is no evidence for four or two electron reduction steps , as would be suggested by the over all reactions from equation no 5 to 9 .

$$
\begin{array}{ll}
\mathrm{O}_{2}+2 \mathrm{H}^{+}+2 \mathrm{e}=\mathrm{H}_{2} \mathrm{O}_{2} & \mathrm{E}^{\mathrm{o}}=+0.682 \mathrm{~V} \\
\mathrm{O}_{2}+\mathrm{H}_{2} \mathrm{O}+2 \mathrm{e}=\mathrm{OH}^{-}+\mathrm{H} \mathrm{O}_{2}^{-} & \mathrm{E}^{\mathrm{o}}=-0.076 \mathrm{~V}
\end{array}
$$

The first step is one electron reduction to the superoxide radical ion $\mathrm{O}_{2}^{-}$.The potential for reduction

$$
\mathrm{O}_{2}+\mathrm{e}=\mathrm{O}_{2}^{-}
$$

Ranges from $\sim-0.2$ to $-0.5 \mathrm{~V}$ depending on the medium. The $\mathrm{O}_{2}{ }^{-}$ion is a moderate reducing agent, comparable to dithionite, and a very weak oxiding agent's .Thus most of the oxidation by $\mathrm{O}_{2}$ is due to peroxide ion $\mathrm{H} \mathrm{O}_{2}{ }^{-}$and $\mathrm{O}_{2}^{2-}$, formed by reaction such as

$$
\begin{array}{r}
\mathrm{H}^{+}+\mathrm{O}_{2}^{-}+\mathrm{e}=\mathrm{H} \mathrm{O}_{2}^{-} \\
2 \mathrm{O}_{2}^{-}+\mathrm{H}_{2} \mathrm{O}=\mathrm{O}_{2}+\mathrm{H} \mathrm{O}_{2}^{-}+\mathrm{OH}^{-}
\end{array}
$$

The oxidation of water to $\mathrm{O}_{2}$ in photosynthetic system in plants has been greatly studied $^{32}$ as have synthetic models such as those of manganese complexes; the oxidation seems occur likely to proceed via $\mathrm{H}_{2} \mathrm{O}_{2}$ rather than $\mathrm{OH}$ Radicals and probably two or four manganese centre are involved ${ }^{33 .}$ It was interesting to know that metanil yellow and $p$-aminodiphenylamine, the two dyes which gave a negative test for ${ }^{1} \mathrm{O}_{2}$, were found to produce $\left(\mathrm{O}_{2}^{-}\right)$in appreciable yields (Figure 2 and 3). Benzanthrone produced $\left(\mathrm{O}_{2}^{-}\right)$in almost the same quantity as produced by anthracene and hematoporphyrin ${ }^{34}$ (Figure 4 ).

\section{Results and Discussion}

Selected dyes and dyestuffs, benzanthrone, orange II, metanil yellow and $p$-ADPA most commonly used in colouring and textile industries as well as food additives were examined for their ability to produce activated oxygen species $\left[{ }^{1} \mathrm{O}_{2}\right.$ and $\left.\left(\mathrm{O}_{2}^{-}\right)\right]$under normal sunlight with a view to investigating the possible occupational health hazard to people through a series of photodynamic oxidation reactions leading to cell damage.

The formation of ${ }^{1} \mathrm{O}_{2}$ by benzanthrone and $\left(\mathrm{O}_{2}^{-}\right)$by metanil yellow, $p$-ADPA and benzanthrone might rise several question about their safety particularly in conjugation with exposure to sunlight. Studies shows that exposure to metanil yellow, $p$-ADPA and benzanthrone may lead to various short and long term skin photosensitization and cell damaging effects.

Photosensitized reactions of dyes leading to the formation of activated oxygen species are believed to be a matter of great concern because the later are involved in the destruction of cells, tissues, phagocytes and certain cancer inducing processes ${ }^{5,7,9,11}$. Moreover, Bickers 
et $a l^{35}$ have demonstrated the destruction of epidermal cytochrome $P-450$ in epidermal microsomes by ${ }^{1} \mathrm{O}_{2}$ generated through photosensitization reactions induced by hematoporphyrin derivatives. Several other studies have also suggested that ${ }^{1} \mathrm{O}_{2},\left(\mathrm{O}_{2}^{-}\right)$and other reactive forms of oxygen play a major role in the UV-induced membrane damaging reaction ${ }^{36-37}$. Although spectroscopic studies of cutaneous photosensitizing agent XVII, benzanthrone were carried out by Reza Dabestani $e t a l^{38}$. The important roles of reactive oxygen species in diseases related to aging and the necessity and benefits of antioxidative netraceuticals in prevention of disease and promotion of healthy aging reported in recent years $^{39-41}$.

\section{Production of ${ }^{1} \mathrm{O}_{2}$ and $\mathrm{O}_{2}{ }^{-}$at different temperature}

Incubation of reagent mixture used for determining ${ }^{1} \mathrm{O}_{2}$ and $\mathrm{O}_{2}{ }^{-}$in the presence of all the test compounds at 0,25 and $50{ }^{\circ} \mathrm{C}$ did not produce any ${ }^{1} \mathrm{O}_{2}$ and $\mathrm{O}_{2}^{-}$. The results were in agreement with our concepts that photo excitation is necessary for the generation of ${ }^{1} \mathrm{O}_{2}$ and $\mathrm{O}_{2}^{-}$species from test compounds under our experimental condition .

\section{Conclusion}

Analysis was carried out of above dyes at concentration range of (1-10 $\mu \mathrm{g} / \mathrm{mL})$ and exposure period (0-25 $\mathrm{min})$ for obtaining dose response relationship and (0-12 $\mathrm{min})$ for determination of $\left(\mathrm{O}_{2}^{-}\right)$production of above dyestuffs. At higher concentration the linearity was disturbed due to lack of penetration of solar radiation through the colloidal system.

\section{References}

1. Fernando A C, Kothari's Economic \& Industrial Guide of India, $34^{\text {th }}$ Edn, Chemicals \& Pharm., Kothari \& Sons, Madras, India. 1982/83, 6-7.

2. Munn A. and Smagghe G, Encyclopaedia of Occupational Health and Safety, Parmeggiani L, Edn., International Labour Organization, Geneva III. Ed., 1983, 699.

3. Joshi A, Khanna S K, Singh G B and Krishnamutri C R, Industrial Health, 1982, 20, 305-313.

4. Joshi A, Khanna S K, Singh G B and Krishnamutri C R, J Biosci., 1981, 3, 379-388.

5. Parrish J A, Anderson R R, Urbach F and Pitts D, UV-A, Biological Effects of Ultraviolet Radiations with Emphasis on Human Responses to Long wave Ultraviolet, Plenum Press, New York, 1978.

6. Prayer W A, Free Radicals in Biology, Academic Press, New York., 1976, 2 , 85-133.

7. Krinsky N I, Singlet Oxygen (H H. Wasserman and R W. Murray, Eds.) Academic Press, New York, 1979, 597-667.

8. Joshi P C, Toxicol Lett., 1985, 26, 211-217.

9. Marx J L, Science, 1983, $219,158-159$.

10. Trivedi D H and Niyogi A K, Indian J Ind Med., 1968, 14, 13.

11. Singh G B and Zaidi S H, J Indian Med Assoc., 1969, 52, 558-560.

12. Gurr E, Synthetic Dyes in Biology, Medicine and Industry, Academic Press, New York, 1971, 237.

13. Singh G B and Khanna S K, Indian J Exp Biol., 1979, 17, 1100-1102

14. Srivastava L P, Khanna S K, Singh G B and Krishnamurti C R, Environ Res., 1982, 27, 185-189.

15. Raza H, Biochemical Studies on Some Food Dyes, Ph.D. Thesis submitted to Kanpur University, India, 1980. 
16. Uniroyal Chemicals, $p$-Aminodiphenylamine, Naugatack (R) Chemicals, Division of Unioryal Inc Naugatack, C.K, 1976.

17. Color Index, The Society of Dyers \& Colourists, England and The American Association of Textile Chemicals \& Colorists, U.S.A., 1971, 2, 2002.

18. Wall F E, Cosmetics Science and Technology, Balasam M S and Sagarin E, Eds., Wiley, New York, 1972, 2, 306.

19. Szamarch H, Przeglad Dermatol., 1966, 53, 445-452.

20. Hatchard C G and Parker C A, Proc R Soc Lond., 1956, 235 , 518-536.

21. Kraljic I. and El Mohsni S, Photochem Photobiol., 1978, 28, 577-581.

22. Foote C S, Fugimoto T T and Chang Y C, Tetrahedron Lett., $1972,45-48$.

23. Quannes C and Wilson T, J Am Chem Soc., 1968, 90, 6527-6528.

24. Kearns D R, Singlet Oxygen, Wasserman H H and Murray RW, Eds., Academics Press, New York, 1979, 115-137.

25. Korycka-Dahl M and Richardson T, J Dairy Sci., 1977, 61, 400-407.

26. McCord J M and Fridovich I, J Biol Chem., 1969, 244, 4049-6055.

27. Lissi E A, Encinas M W, Lemp E and Rubio M A, Chem Rev., 1993, 93, 699.

28. Chou P T, Wei G T, Lin C H, Wei C Y and Chang C H, J Am Chem Soc., 1996, 118, 3031.

29. Nau W M and Foote C S, J Am Chem Soc., 1996, 118, 2742.

30. Karlin K D, Zabieta Jon, Chen Qin, Murthy N N and Wei Ning, Inorg Chem., 1994, 33, 1953.

31. Van Eldik R, Istvan Fabian and Christian Brandt, Inorg Chem., 1994, 33, 687.

32. Brad A J and Fox M A, Acc Chem Res., 1995, 28, 141.

33. Armstrong W H, Wright David W and Christopher E Dube, J Am Chem Soc., 1996, 118, 10910.

34. Joshi P C and Pathak M A, Biochem Biophys Res Commun., 1983, 112, 638-646.

35. Bickers D R, Dixit R and Mukhtar H, Biochem Biophys Res Commun., 1982, 108, 1032-1039.

36. Ito T, Photochem Photobiology, 1978, 28, 493-508.

37. Anderson S M, Krinsky N I, Stone M R and Clagett D C, Photochem Photobiol., 1974, 20, 65-69.

38. Robert H, Photochem Photobiol., 1992, 55(4), 533-539.

39. Galey J B, Int J Cosmet Sci., 1991, 13(2), 65-78.

40. Riley P A, Int J radiat boil., 1994, 65(1), 27-33.

41. Lee J, Koo N and Min D B, Comprehensive Reviews in Food Science and Safety, 2004, 3(1), 21-33. 


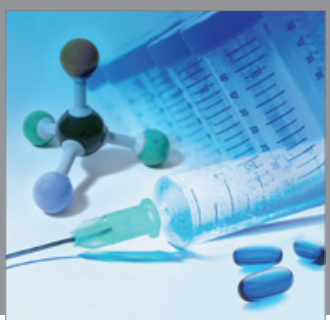

International Journal of

Medicinal Chemistry

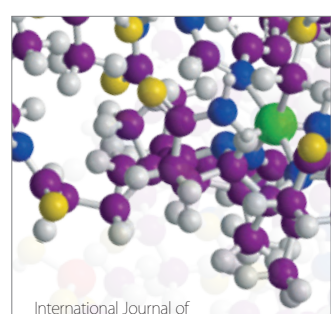

Carbohydrate Chemistry

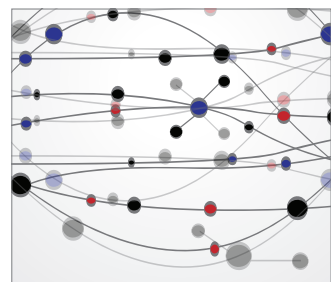

The Scientific World Journal
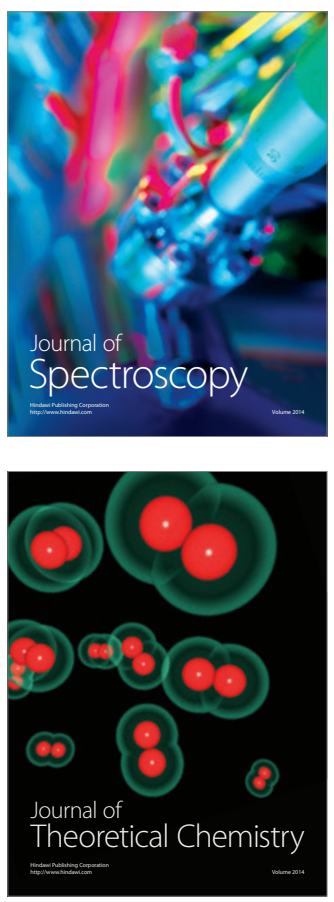
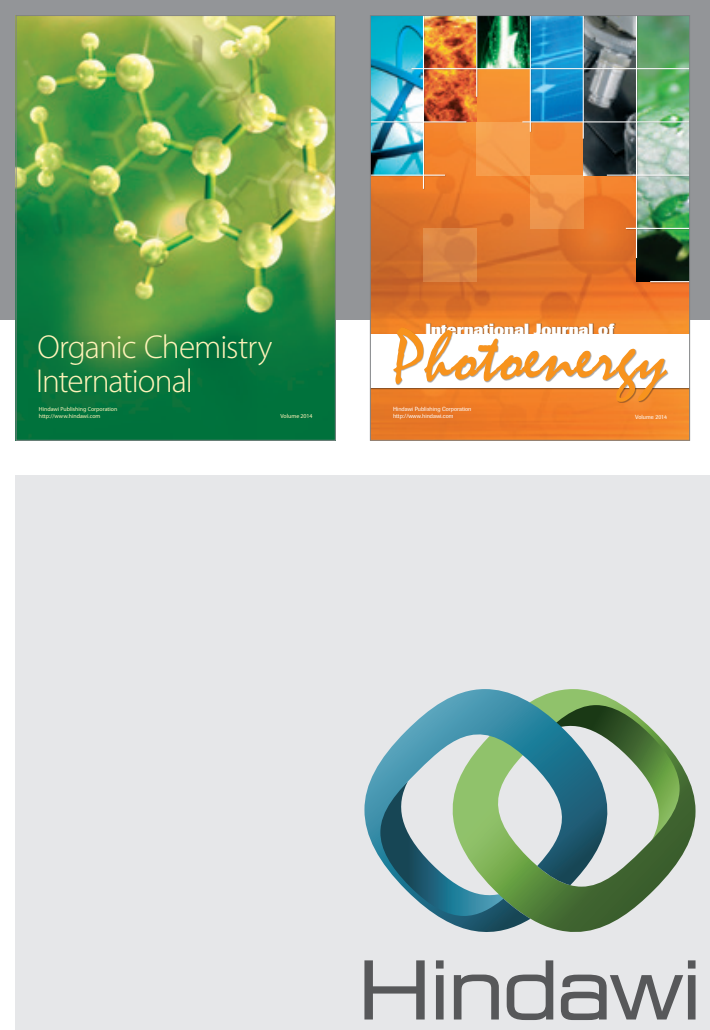

Submit your manuscripts at

http://www.hindawi.com
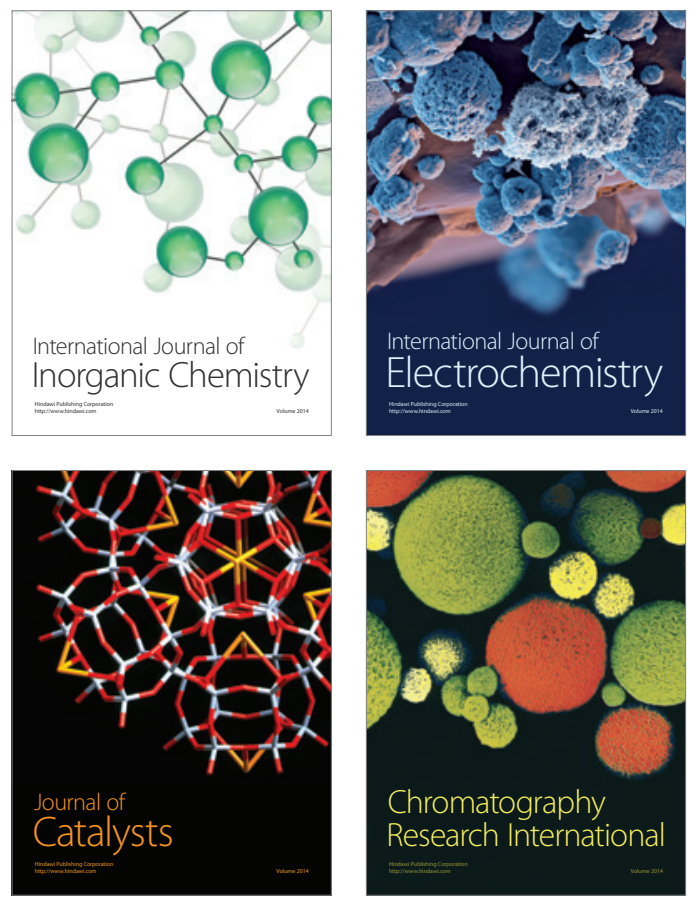
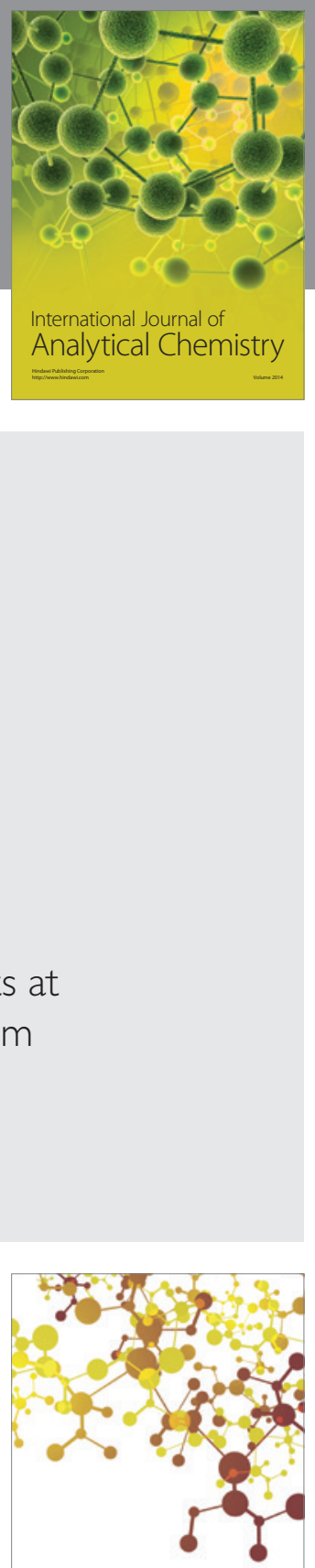

Journal of

Applied Chemistry
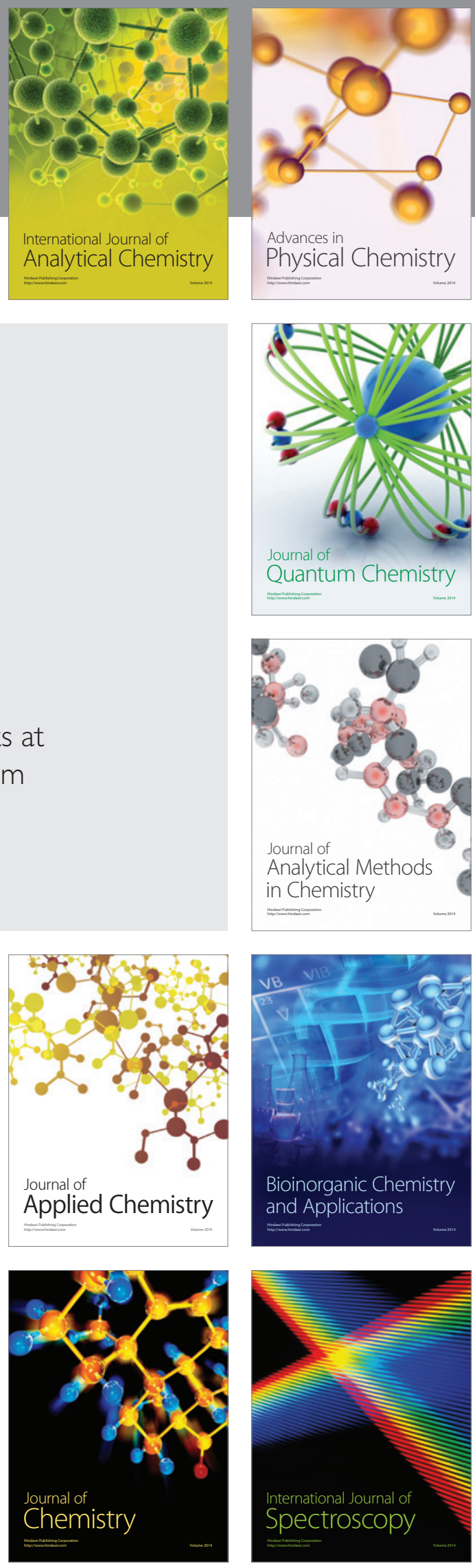